Distribution Category: UC-504

Materials

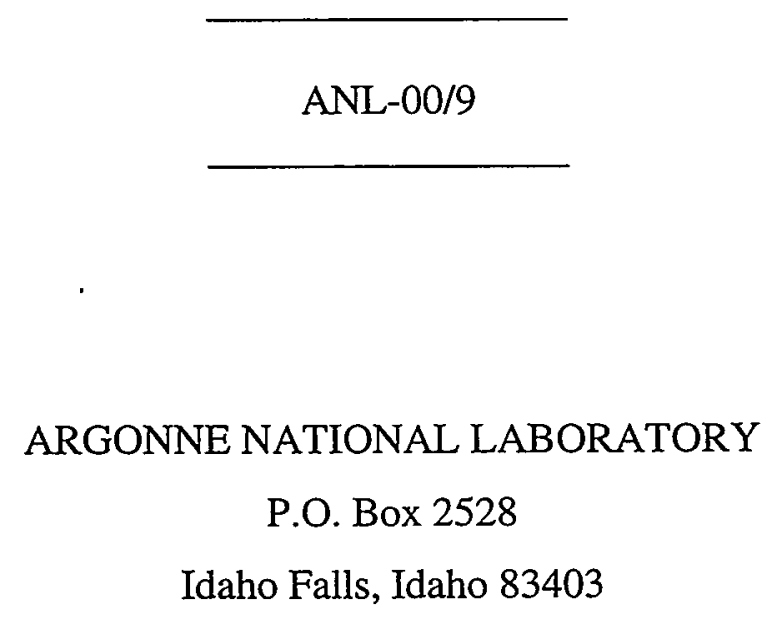

Characterization of Degraded EBR-II Fuel from the ICPP-603 Basin: National Spent Nuclear Fuel Program FY 1999 Final Report

by

R. G. Pahl

Engineering Division

Argonne National Laboratory - West

April 2000 


\section{DISCLAIMER}

This report was prepared as an account of work sponsored by an agency of the United States Government. Neither the United States Government nor any agency thereof, nor any of their employees, make any warranty, express or implied, or assumes any legal liability or responsibility for the accuracy, completeness, or usefulness of any information, apparatus, product, or process disclosed, or represents that its use would not infringe privately owned rights. Reference herein to any specific commercial product, process, or service by trade name, trademark, manufacturer, or otherwise does not necessarily constitute or imply its endorsement, recommendation, or favoring by the United States Government or any agency thereof. The views and opinions of authors expressed herein do not necessarily state or reflect those of the United States Government or any agency thereof. 


\section{DISCLAIMER}

\section{Portions of this document may be illegible in electronic image products. Images are produced from the best available original document.}


TABLE OF CONTENTS

$\underline{\text { Page }}$

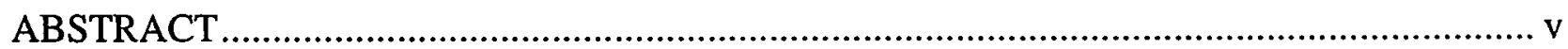

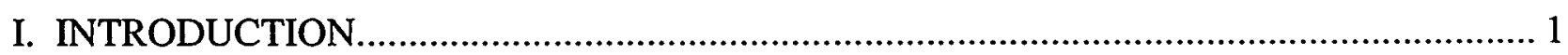

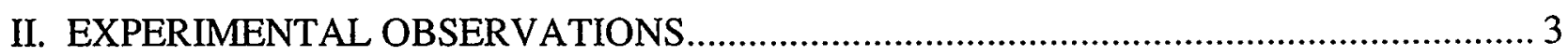

A. As-Received Visual and Neutron Radiography Examinations ............................................. 3

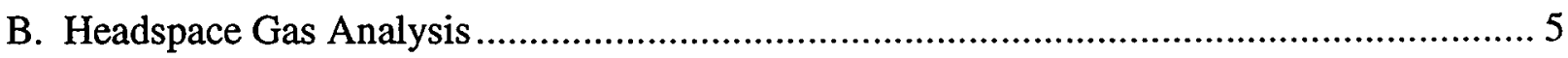

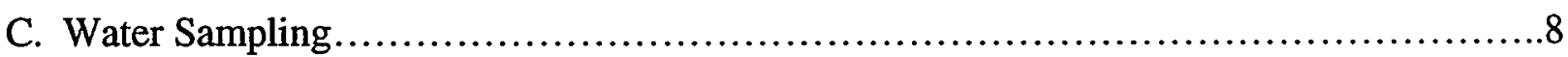

D. Neutron Radiography after Draining ............................................................................. 11

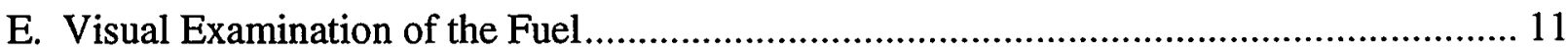

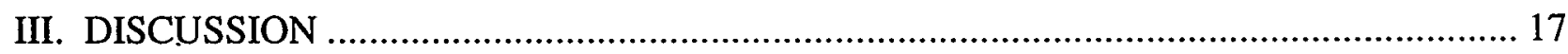

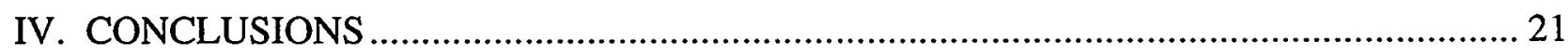

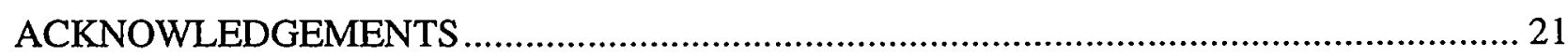

REFERENCES 


\section{LIST OF FIGURES}

Figure 1. Photograph of the IV-8 and KH-4 containers as-received at HFEF .......................... 4

Figure 2. Neutron radiograph of the bottom of container DR-2, showing it to be still dry ......... 7

Figure 3. In-cell operation of draining the water from the IV-8 container .............................. 10

Figure 4. Neutron radiographs of the IV-8 container, before (left) and after draining (two at

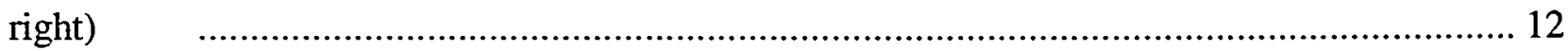

Figure 5. EBR-II fuel element removed from the IV-8 container ........................................ 13

Figure 6. Degraded EBR-II fuel exposed for examination after cutting open the IV-8

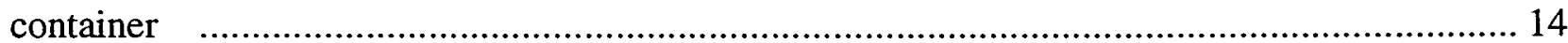

Figure 7. Degraded EBR-II fuel exposed for examination after cutting open the IV-8 container 15

Figure 8. Degraded EBR-II fuel exposed for examination after cutting open the IV-8 container

\section{LIST OF TABLES}

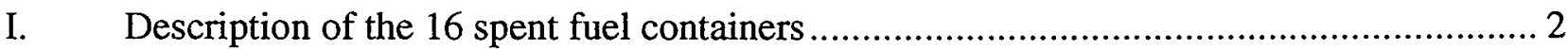

II. Lid closure data and results of as-received neutron radiography .................................... 6

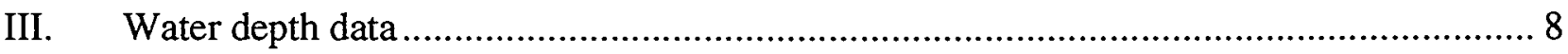

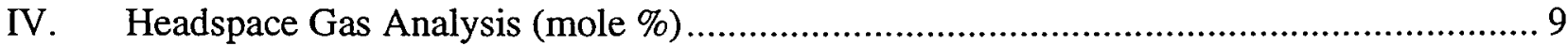

V. Radiochemical Analyses of Water Samples (microcuries/ml) ....................................... 9 


\title{
Characterization of Degraded EBR-II Fuel from the ICPP-603 Basin: National Spent Nuclear Fuel Program FY 1999 Final Report
}

\author{
by
}

R. G. Pahl

\begin{abstract}
Characterization data is reported for sodium bonded Experimental Breeder Reactor II (EBR-II) fuel which had been stored underwater in containers since the late 1970's. Sixteen stainless steel storage containers were retrieved from the ICPP-603 storage pool at the Idaho National Engineering and Environmental Laboratory (INEEL) in Idaho. Ten of the containers had leaked water due to improper sealing. In the container chosen for detailed destructive analysis, the stainless steel cladding on the uranium alloy fuel had ruptured and fuel oxide particulate formed and filled the bottom of the container. Headspace gas analysis determined that greater than $99 \%$ hydrogen was present. Cesium-137, which had leached out of the fuel during the aqueous corrosion process, dominated the radionuclide source term of the water. The metallic sodium from the fuel element bond had reacted with the water, forming a caustic solution of $\mathrm{NaOH}$.
\end{abstract}




\section{INTRODUCTION}

The termination of aqueous reprocessing at the former Idaho Chemical Processing Plant (ICPP) at the INEEL site has left approximately 2 metric tons heavy metal (MTHM) of irradiated EBR-II fuel in temporary pool storage. As of this writing, future disposition [1] of this and similar sodium-bonded fuel has yet to be determined by the U.S. Department of Energy. This fuel [2], known as "uranium fissium", is a uranium-noble metal alloy [95U2.4Mo-1.9Ru-0.3Rh-0.2Pd-0.1Zr (wt.\%)] clad in austenitic stainless steel (316 or 304L). Beginning in 1978, EBR-II fuel destined for reprocessing was encapsulated in stainless steel containers prior to pool storage. The purpose of the containers was to prevent pool water from coming into direct contact with the fuel elements, as corrosion and fuel degradation had been observed in the past [3]. There are over 3600 of these containers in two storage pools (ICPP603 / ICPP-666) at the INEEL. Each of the cylindrical containers $[\sim 5 \mathrm{cms}$. ( 2 inches) diameter $x 77.5 \mathrm{cms}$ (30.5 inches) long] holds up to approximately $0.7 \mathrm{kgs}$ of highly enriched uranium. Visual observation of bubbling and subsequent ultrasonic inspection at the ICPP-603 storage pool in 1996 identified 11 potentially leaking containers. These containers, along with 5 intact "controls", were shipped in January of 1998 to the Hot Fuel Examination Facility (HFEF) at the Argonne National Laboratory-West (ANL-W) site in Idaho. The fuel shipment was accomplished using the ANL-W HFEF-6 cask, which was the original cask used in the late 1970's between ANL and the ICPP basins.

Table I describes the contents of the 16 containers as given on the original fuel records (HFEF form F-5). The 16 containers represent 4 separate cask shipments. The first 11 entries in Table I were identified by INEEL staff to be "suspect" leakers. All of the IE series bubbled during in-basin handling except IE-2, but ultrasonic data showed all of them contained water. Containers IV-8 and KH-4 were shipped seperately, bubbled during handling and were judged water-filled by the ultrasonic data. The DR series represents the oldest EBR-II fuel in the basin and neither bubbled nor tested positive on the ultrasonic test with the exception of DR-2. This container gave an ultrasonic signal which was near the limit of detection for water levels. Interpretation of the individual ultrasonic signatures for the bottles inspected suggested that 8 of the leaking containers definitely contained some solid particulate, suggesting that corrosion 
Table I. Description of the 16 spent fuel containers

\begin{tabular}{|c|c|c|c|c|c|}
\hline $\begin{array}{c}\text { Container } \\
\text { ID } \\
\text { Number }\end{array}$ & $\begin{array}{c}\text { Subassembly } \\
\text { Number, Fuel } \\
\text { Type }\end{array}$ & $\begin{array}{c}\text { Date Last } \\
\text { Irradiated in } \\
\text { EBR-II }\end{array}$ & $\begin{array}{c}\text { \% Burnup } \\
\text { as listed on } \\
\text { HFEF Form } \\
\text { F-5 }\end{array}$ & $\begin{array}{c}\text { Number } \\
\text { of } \\
\text { Elements }\end{array}$ & $\begin{array}{c}\text { Date Shipped } \\
\text { to ICPP-603 } \\
\text { Basin }\end{array}$ \\
\hline IE-1 & X274A, MK-II & $6-5-79$ & 11.1 avg. & 12 & $3-12-82$ \\
\hline IE-2 & X274A, MK-II & $6-5-79$ & 11.1 avg. & 12 & $3-12-82$ \\
\hline IE-3 & X274A, MK-II & $6-5-79$ & 11.1 avg. & 12 & $3-12-82$ \\
\hline IE-4 & X274A, MK-II & $6-5-79$ & 11.1 avg. & 12 & $3-12-82$ \\
\hline IE-5 & X274A, MK-II & $6-5-79$ & 11.1 avg. & 12 & $3-12-82$ \\
\hline IE-6 & X274A, MK-II & $6-5-79$ & 11.1 avg. & 12 & $3-12-82$ \\
\hline IE-7 & X274A, MK-II & $6-5-79$ & 11.1 avg. & 12 & $3-12-82$ \\
\hline IE-8 & X274A, MK-II & $6-5-79$ & 11.1 avg. & 4 & $3-12-82$ \\
\hline IV-8 & L-4171-S, MK-IA & $10-6-79$ & 2.30 max. & 12 & $12-4-81$ \\
\hline KH-4 & B-3450-A, MK-II & $8-17-81$ & 7.89 max. & 11 & $1-11-82$ \\
\hline DR-2 & B-3328-MK-II & $7-31-78$ & 7.64 max. & 12 & $11-7-78$ \\
\hline DR-3 & B-3328-MK-II & $7-31-78$ & 7.64 max. & 12 & $11-7-78$ \\
\hline DR-5 & B-3328-MK-II & $7-31-78$ & 7.64 max. & 11 & $11-7-78$ \\
\hline DR-6 & B-3328-MK-II & $7-31-78$ & 7.64 max. & 11 & $11-7-78$ \\
\hline DR-7 & B-3328-MK-II & $7-31-78$ & 7.64 max. & 11 & $11-7-78$ \\
\hline DR-8 & B-3328-MK-II & $7-31-78$ & 7.64 max. & 11 & $11-7-78$ \\
\hline
\end{tabular}

had indeed taken place and that sludge had likely formed.

The objective of the characterization activities reported here was to determine the physical and chemical condition of the fuel after contact with the water in order to understand the risks of radionuclide release to the environment and to assess the possibility of combustion events during handling or transportation. Characterization data is also needed to identify the best stabilization treatment for this fuel prior to final disposal.

An assessment [3] written in 1996 explored the effects of in-leakage of water and the expected corrosion and failure of the stainless steel cladding and subsequent uranium alloy oxidation. That assessment predicted the extent of fuel degradation which may occur, which has now been verified and described below. 


\section{EXPERIMENTAL OBSERVATIONS}

\section{A. As-Received Visual and Neutron Radiography Examinations}

The 16 fuel storage containers were sent to HFEF in two overpack shipping containers (SF56-2 and SF56-3 containers) which were designed to provide additional containment and structural integrity during handling and transit within the HFEF-6 shipping cask. The overpacks were filled with pool water prior to sealing in order to mitigate a postulated combustion event from any uranium hydride present should the fuel containers lose their internal water and dry out. The overpack water was sampled and the results reported below in section II. D.

The two overpack containers were opened in HFEF and the 16 fuel containers retrieved for characterization. The general external condition of the 16 fuel storage containers was good. No obvious evidence of general corrosion, pitting or handling damage could be seen. Figure 1 shows containers IV-8 and $\mathrm{KH}-4$ as photographed through the hotcell window. The ID numbers written with a felt marker pen are still visible after $\sim 16$ years in the pool water. Each of the 16 containers was visually examined and data recorded pertaining to the tightness of the hexagonal nut which seals the lid. A fiducial mark had been applied prior to fuel loading that showed the hotcell technicians at ANL-W where the lid should be positioned for "finger" tightness. Once the fuel was loaded in the hotcell the lid was tightened with a wrench $1 / 6$ of a revolution beyond finger tightness. Table II shows the degree of tightness of the lids. All of the containers which neutron radiographs proved to be water filled had loose lids as judged by the alignment of the fiducial mark and lid retightening behavior. One container (IE-8), which later proved to be essentially full of water, had a lid which was a full turn less than "finger" tight. All of the DR series containers, (later judged dry in the neutron radiographs), had tight lids with fiducial marks that lined up correctly per the original procedure. The loose lids were manually tightened shortly after receipt in order to insure safe handling and containment during examination. 


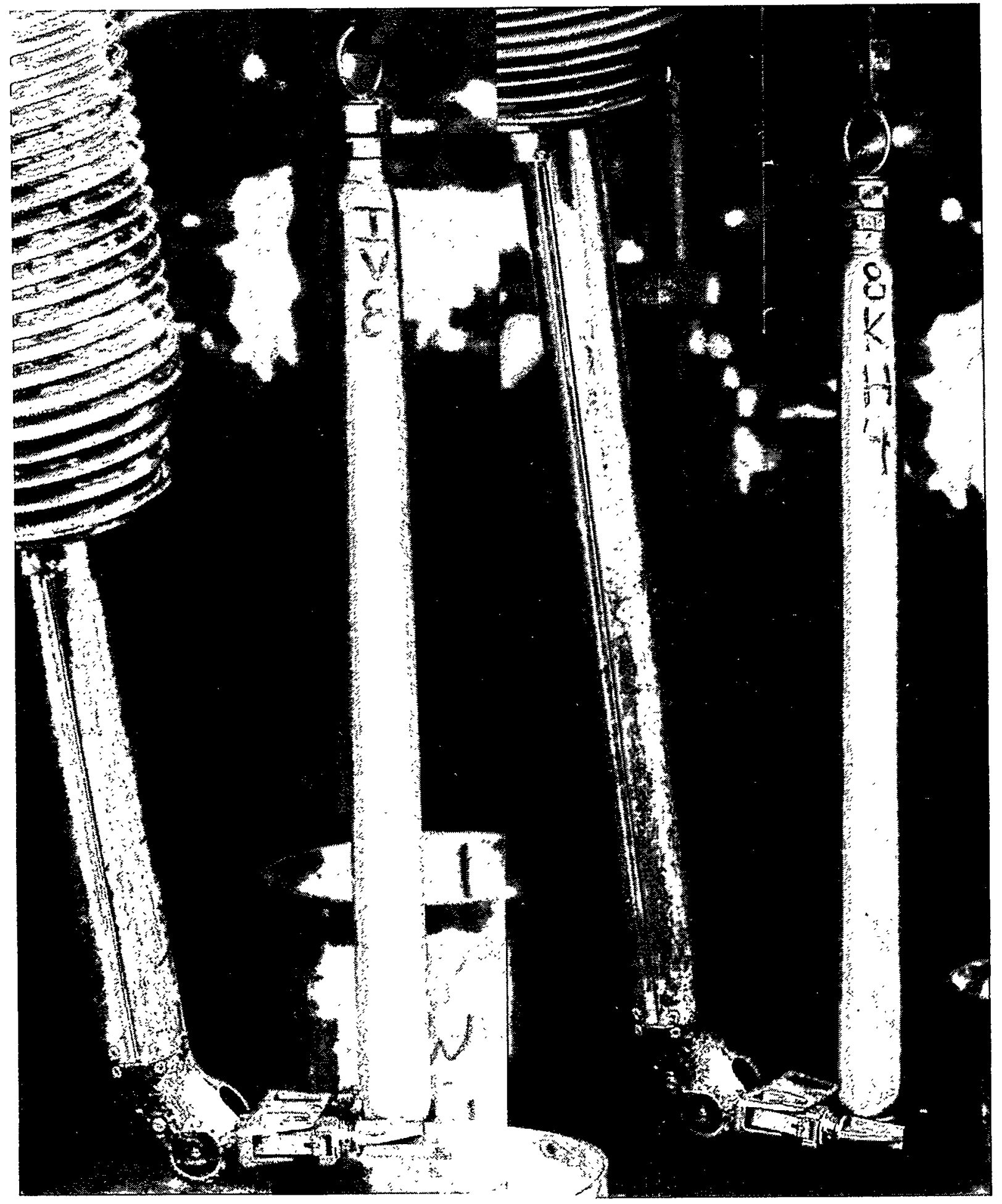

Figure 1. Photograph of the IV-8 and KH-4 containers as-received at HFEF 
Neutron radiography was performed to image the container contents in order to verify the results from the previous ultrasonic testing for water level and to assess any gross fuel damage, sludge formation, etc. All 16 containers were radiographed in the as-received condition at the TRIGA reactor facility in HFEF. Because water attenuates the transmitted neutron beam, water level is clearly distinguishable from the container internals in the resulting radiographs. However, the container, fuel and cladding structure are only visible in the regions not masked by the water. Radiographs of 10 of the 11 suspect leakers clearly showed water as shown in Table II.

In most cases significantly more water was imaged by radiography than the ultrasonic tests had indicated. Table III compares the water depth as measured by ultrasonics and neutron radiography. With the exception of the IV-8 container which had a water level virtually unchanged between measurements, water depth ranged from $32 \%$ to $166 \%$ greater than previously measured by ultrasonic data. This is likely the result of leakage during the intervening 2 years between ultrasonic testing and removal from the pool rather than a systematic error in the ultrasonic data. One false positive result for ultrasonic testing was found for the DR-2 container in which the neutron radiography showed a dry container whereas previous ultrasonic data indicated 5-18 mls of water. This level is near the limit of detection by the ultrasonic technique. The neutron radiograph of DR-2 is shown in figure 2 at $\sim 2 \mathrm{X}$. The containers that had leaked were $\sim 1 / 3$ to completely filled with water. In the leaking containers above the water level, fuel condition varied widely and ranged from apparently intact to breached and clearly fragmented. The 6 non-leaking containers held fuel which was fully visible in the radiographs and which appeared intact and in good condition after $\sim 20$ years of dry storage.

\section{B. Headspace Gas Analysis}

Three of the water filled containers (ID \#s IE-7, IE-2, and IV-8) were chosen for headspace gas sampling. They represented minimal, moderate, and severe fuel disruption, respectively, as judged by the as-received neutron radiography. During the original fuel loading, the containers had been filled with ambient hot cell air. A special apparatus was 
designed to capture the headspace gas by unscrewing the lid while the container was held in an evacuated, calibrated chamber. Gas samples were collected from each container and analyzed by mass spectrometry. Water vapor in the gas samples was cold-trapped prior to gas analysis. Table IV summarizes the gas analyses.

Table II. Lid closure data and results of as-received neutron radiography

\begin{tabular}{|c|c|c|}
\hline Container ID\# & $\begin{array}{c}\text { Lid Rotation for } \\
\text { Correct Tightness }\end{array}$ & Condition of Fuel Elements \\
\hline IE-1 & $90^{\circ}$ & Fuel region masked by water \\
\hline IE-2 & $15^{\circ}$ & Water in plena, some fuel disruption \\
\hline IE-3 & $15^{\circ}$ & Fuel region masked by water \\
\hline IE-4 & $60^{\circ}$ & Water in plena, fuel region masked by water \\
\hline IE-5 & $30^{\circ}$ & Water in plena, fuel region masked by water \\
\hline IE-6 & $30^{\circ}$ & Elements completely submerged \\
\hline IE-7 & $15^{\circ}$ & Water in plena, fuel region masked by water \\
\hline IE-8 & $430^{\circ}$ & Elements completely submerged \\
\hline IV-8 & $60^{\circ}$ & Water in plena, gross fuel disruption \\
\hline KH-4 & $70^{\circ}$ & Water in plena, fuel region masked by water \\
\hline DR-2 & Tight & Appear Intact \\
\hline DR-3 & Tight & Appear Intact \\
\hline DR-5 & Tight & Appear Intact \\
\hline DR-6 & Tight & Appear Intact \\
\hline DR-7 & Tight & Appear Intact \\
\hline DR-8 & Tight & Appear Intact \\
\hline
\end{tabular}

Neglecting the anomalous argon/nitrogen content in container IE-2, which is due to accidental in-leakage of hotcell atmosphere into the container or sampling equipment, all 3 containers held predominately hydrogen gas. Traces of $\mathrm{Kr}$ and $\mathrm{Xe}$ fission gas were measured and the oxygen content was below the $0.01 \%$ detection limit. Pressure estimates were made using the known gas collection system volumes and fuel container gas volumes estimated from 
the radiography. The resulting pressures were $\sim 1.9$ and $\sim 3.1$ atmospheres for containers IV -8 and IE-7, respectively.
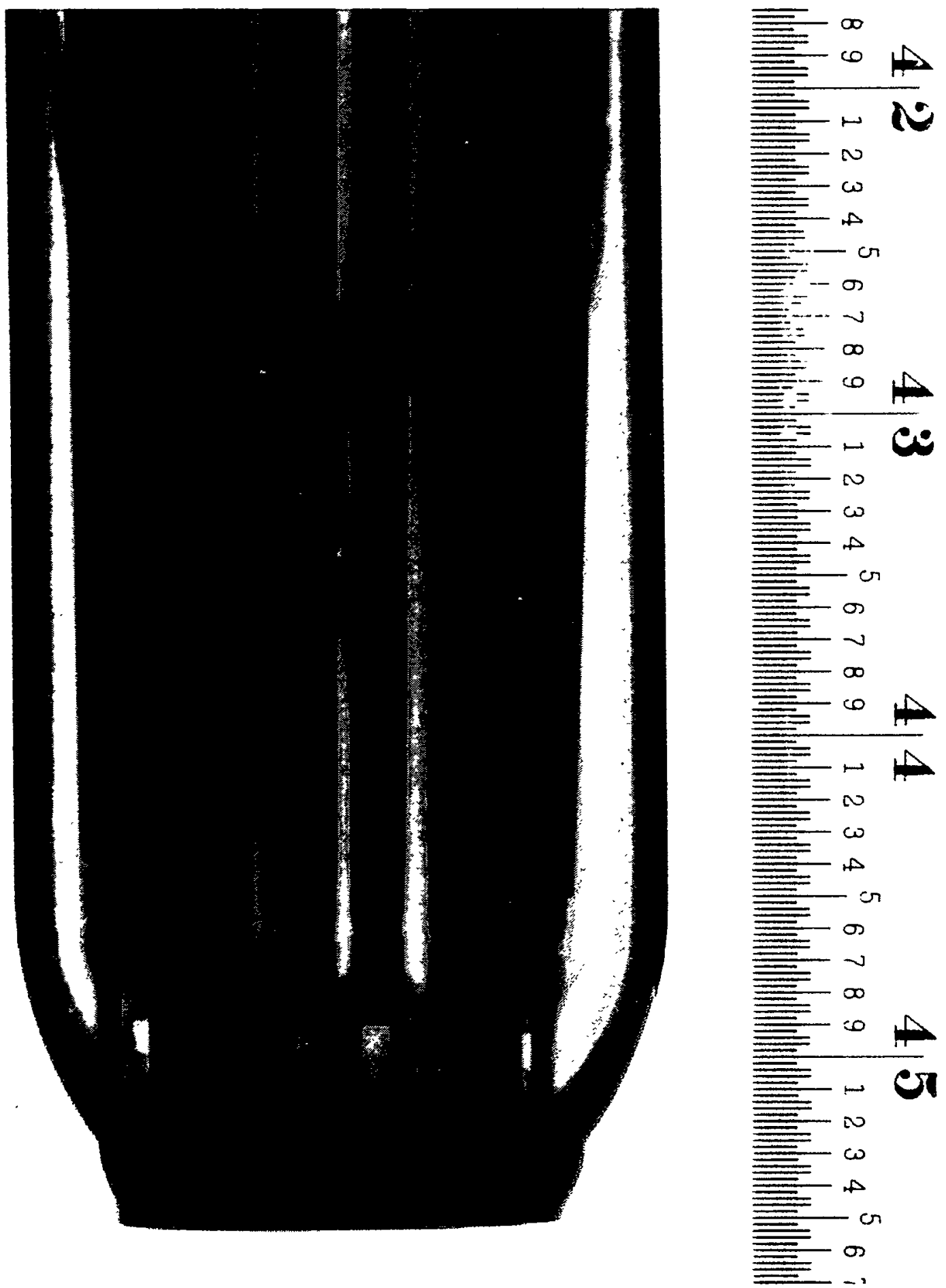

Figure 2. Neutron radiograph of the bottom of container DR-2, showing it to be still dry 
Table III. Water depth data

\begin{tabular}{|c|c|c|}
\hline $\begin{array}{c}\text { Container } \\
\text { ID\# }\end{array}$ & $\begin{array}{l}\text { Water Depth by } \\
\text { Ultrasound at Basin }\end{array}$ & $\begin{array}{c}\text { Water Depth by } \\
\text { Neutron Radiography }\end{array}$ \\
\hline$\overline{\mathrm{IE}}-1$ & $>17.6^{\prime \prime}$ (limit of test) & $23.4 "$ \\
\hline IE-2 & $7.9 "$ & $14.1^{\prime \prime}$ \\
\hline IE-3 & $>17.6^{\prime \prime}$ (limit of test) & $23.6 "$ \\
\hline IE-4 & $10.7^{\prime \prime}$ & $18.1 "$ \\
\hline IE-5 & $10.1 "$ & $14.9 "$ \\
\hline IE-6 & $>17.6 "$ (limit of test) & $24.8 "$ \\
\hline IE-7 & $7.6^{\prime \prime}$ & $16.3^{\prime \prime}$ \\
\hline EE-8 & $9.5 "$ & $25.3^{\prime \prime}$ \\
\hline IV-8 & $10 "$ & $9.7 "$ \\
\hline $\mathrm{KH}-4$ & $15.5^{\prime \prime}$ & $20.5 ”$ \\
\hline$\overline{D R}-2$ & $\sim 0.1 "$ to $0.4 "(5-18 \mathrm{ml})$ & dry \\
\hline DR-3 & dry & dry \\
\hline$\overline{D R}-5$ & dry & dry \\
\hline DR-6 & dry & dry \\
\hline DR-7 & dry & dry \\
\hline$\overline{\mathrm{DR}}-8$ & dry & dry \\
\hline
\end{tabular}

\section{Water Sampling}

Samples of the water from the two shipping overpack containers and from fuel container IV-8 were analyzed. Figure 3 shows the IV-8 container in the tipping apparatus with a Tygon hose attached. Approximately $243 \mathrm{ml}$ of lightly discolored water was collected by decanting the IV-8 container. An unfiltered sample was taken by syringe and sent to the ANL-W Analytical Laboratory for analysis. Table $\mathrm{V}$ compares the results with recent typical analyses obtained for water from the ICPP-603 pool at the INEEL. 
Table IV. Headspace Gas Analysis (mole \%)

\begin{tabular}{|c|c|c|c|}
\hline & IE-7 & IE-2 & IV-8 \\
\hline Hydrogen $\left(\mathrm{H}_{2}\right)$ & 99.23 & 48.9 & 99.94 \\
\hline Helium & $<0.01$ & $<0.01$ & $<0.01$ \\
\hline Ntrogen $\left(\mathrm{N}_{2}\right)$ & $<0.01$ & 0.81 & $<0.01$ \\
\hline Oxygen $\left(\mathrm{O}_{2}\right)$ & $<0.01$ & $<0.01$ & $<0.01$ \\
\hline Argon & 0.04 & 50.3 & 0.05 \\
\hline Carbon Dioxide & $<0.01$ & 0.01 & $<0.01$ \\
\hline Krypton & 0.10 & $<0.01$ & $<0.01$ \\
\hline Xenon & 0.62 & 0.04 & 0.01 \\
\hline
\end{tabular}

Table V. Radiochemical Analyses of Water Samples (microcuries/ml)

\begin{tabular}{|c|c|c|c|}
\hline Sample Origin & Cs-137 & Cs-134 & Sr-90 \\
\hline ICPP-603 Pool & $1 \times 10^{-4}$ & $1.7 \times 10^{-8}$ & $8.6 \times 10^{-5}$ \\
\hline SF56-2 Overpack & 5.5 & $2.4 \times 10^{-3}$ & - \\
\hline SF56-3 Overpack & $2.1 \times 10^{-2}$ & - & - \\
\hline IV-8 Container & $2.3 \times 10^{4}$ & - & 0.65 \\
\hline
\end{tabular}

Other analytes (by weight) in the IV-8 container water were: $\mathrm{U}<0.8 \mathrm{ppm}, \mathrm{Pu} 4 \mathrm{ppb}$, Mo $320 \mathrm{ppm}, \mathrm{Cr}<0.1 \mathrm{ppm}, \mathrm{Cd}<0.1 \mathrm{ppm}, \mathrm{Pb}<0.3 \mathrm{ppm}$, Cs $657 \mathrm{ppm}$, and $\mathrm{Na} 1403 \mathrm{ppm}$ (where < indicates the detection limit). The $\mathrm{Na}$ concentration corresponds to $\sim 0.34$ grams in the $243 \mathrm{mls}$ of IV-8 water collected. This quantity of sodium (added to the cladding jacket as a thermal bond) corresponds to $\sim 45 \%$ of one fuel elements' sodium content. Sodium (and cesium which behaves similarly) may be present in the form of solid precipitate compounds within the mass of sludge and will be investigated further when sludge samples become available. The relatively high Mo content may be due to sodium molybdate which has a high solubility in the water. 


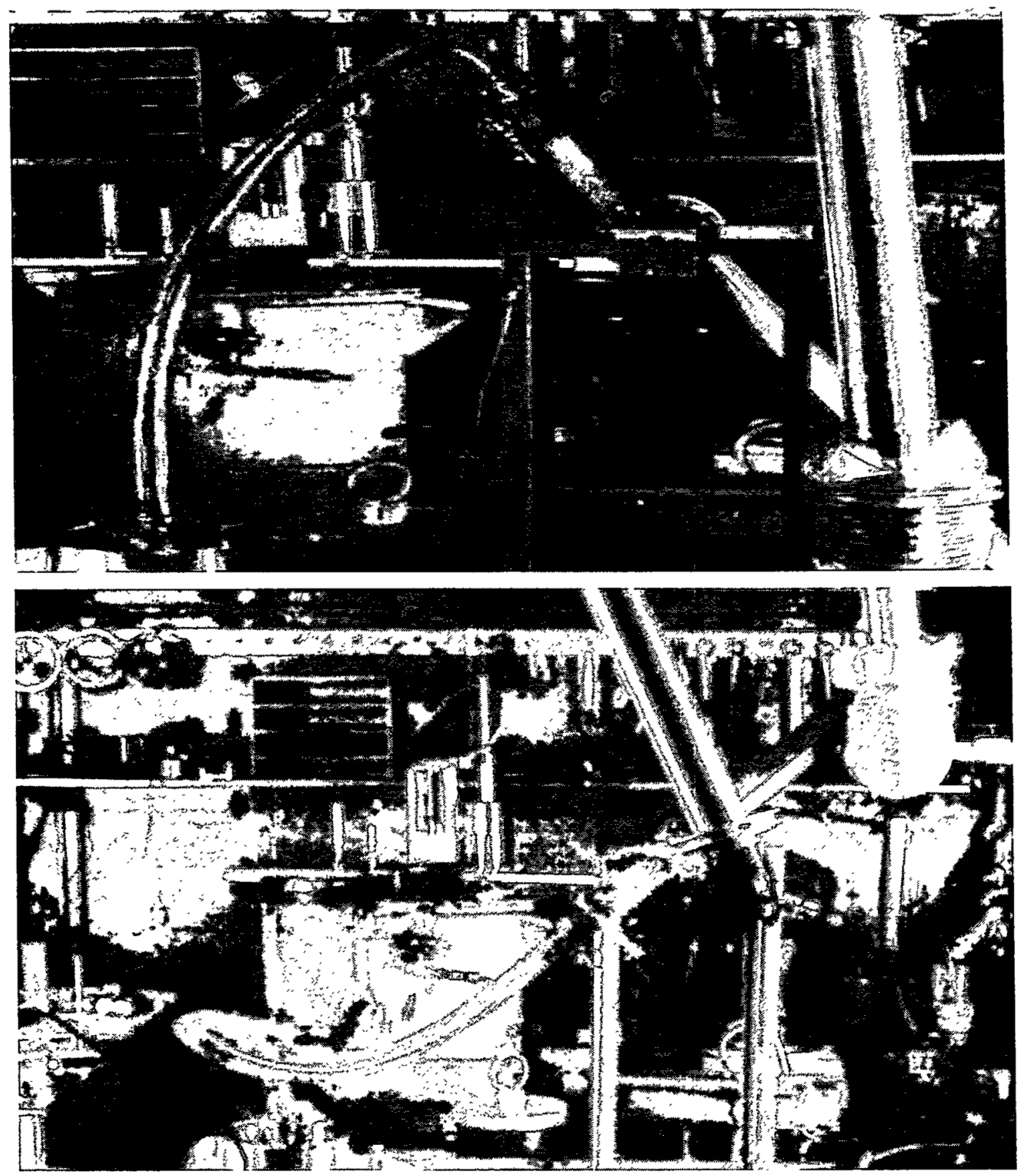

Figure 3. In-cell operation of draining the water from the IV-8 container 


\section{Neutron Radiography after Draining}

Fuel container IV-8 was re-capped after draining the water and re-radiographed. Figure 4 shows the radiographs before and after draining the water, illustrating the masking effects of the water. The water depth was $\sim 25 \mathrm{~cm}$ (10 in.), covering $\sim 2 / 3$ of the fuel column height. The two images at left are thermal neutron images, while that at right is an epithermal neutron image. The right hand images show severe fuel corrosion and the resulting layer of fuel debris in the bottom of the container. It appears that 6 of the 12 elements have lost the lower half of their fuel columns to this debris bed. Close inspection of the neutron radiograph showed the cladding rupture to be a wide serrated crack running lengthwise along the various fuel elements. Though tipped to 45 degrees below horizontal for draining, the debris bed appears to have remained essentially intact, with no trace of loose fuel particulate left on the side of the container. This was somewhat unexpected because of the normally flocculent nature of the corrosion products. Fuel cladding rupture and fuel alloy corrosion has also obviously taken place in the fuel column region in the gas headspace above the high water line. A number of the elements also contain water trapped within their plenum regions above the fuel column and high water level. Figure 4 shows this feature as the dark region in the plenum between the fuel column and upper cladding closure weld. Note that the element protruding up above the rest has plenum water that has actually increased in depth between the initial and final radiographs.

\section{E. Visual Examination of the Fuel}

The EBR-II fuel containers were designed to be loaded only once with fuel and reprocessed as is, i.e. never unloaded prior to dissolution. Therefore, it was necessary to open the IV-8 container by sectioning transversely to retrieve the fuel elements. A conventional tubing cutter was used to cut the container at two elevations, 16 inches $(41 \mathrm{~cm})$ and 6 inches $(15 \mathrm{~cm})$ from the bottom. After cutting, the inner surface of the stainless steel container was found to be in good condition and appeared shiny despite $\sim 20$ years in storage. The fuel element that is seen protruding higher than the rest in figure 4 easily came free after the first 


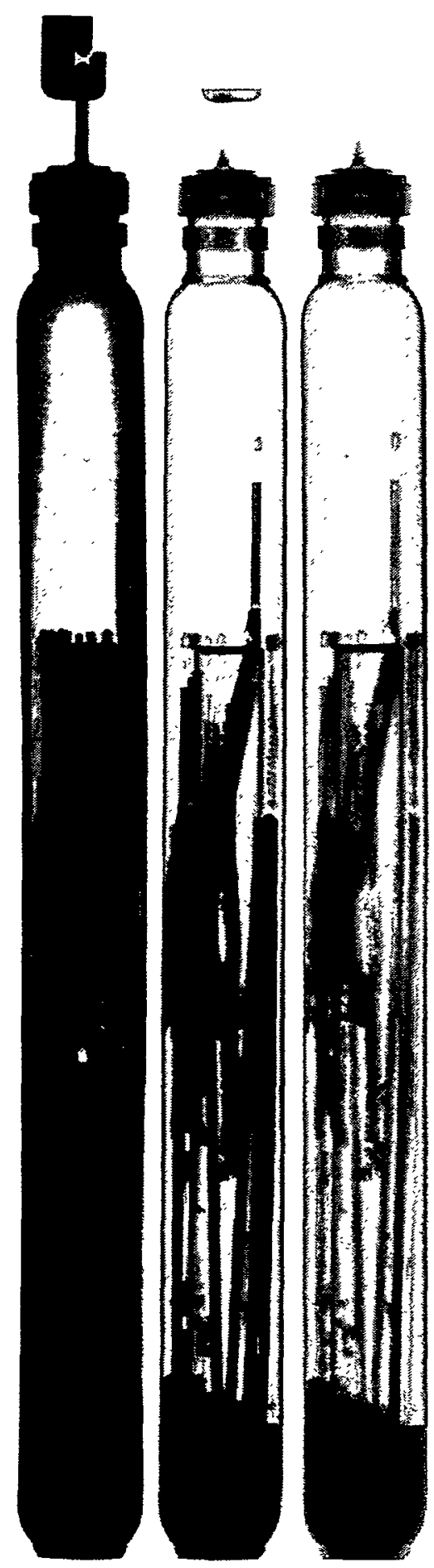

Figure 4. Neutron radiographs of the IV-8 container, before (left) and after draining (two at right) 


$$
7
$$




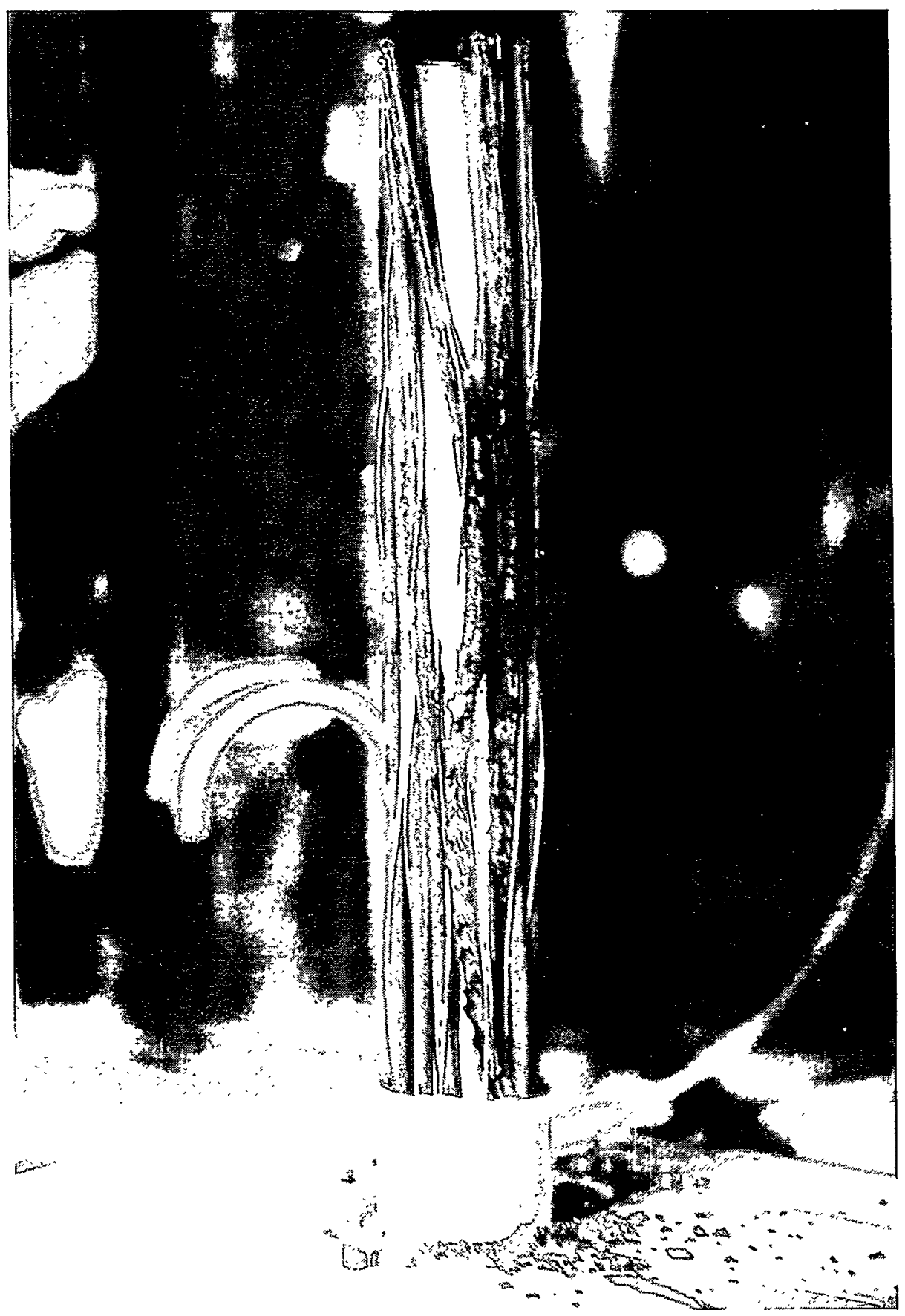

Figure 6. Degraded EBR-II fuel exposed for examination after cutting open the IV-8 container 


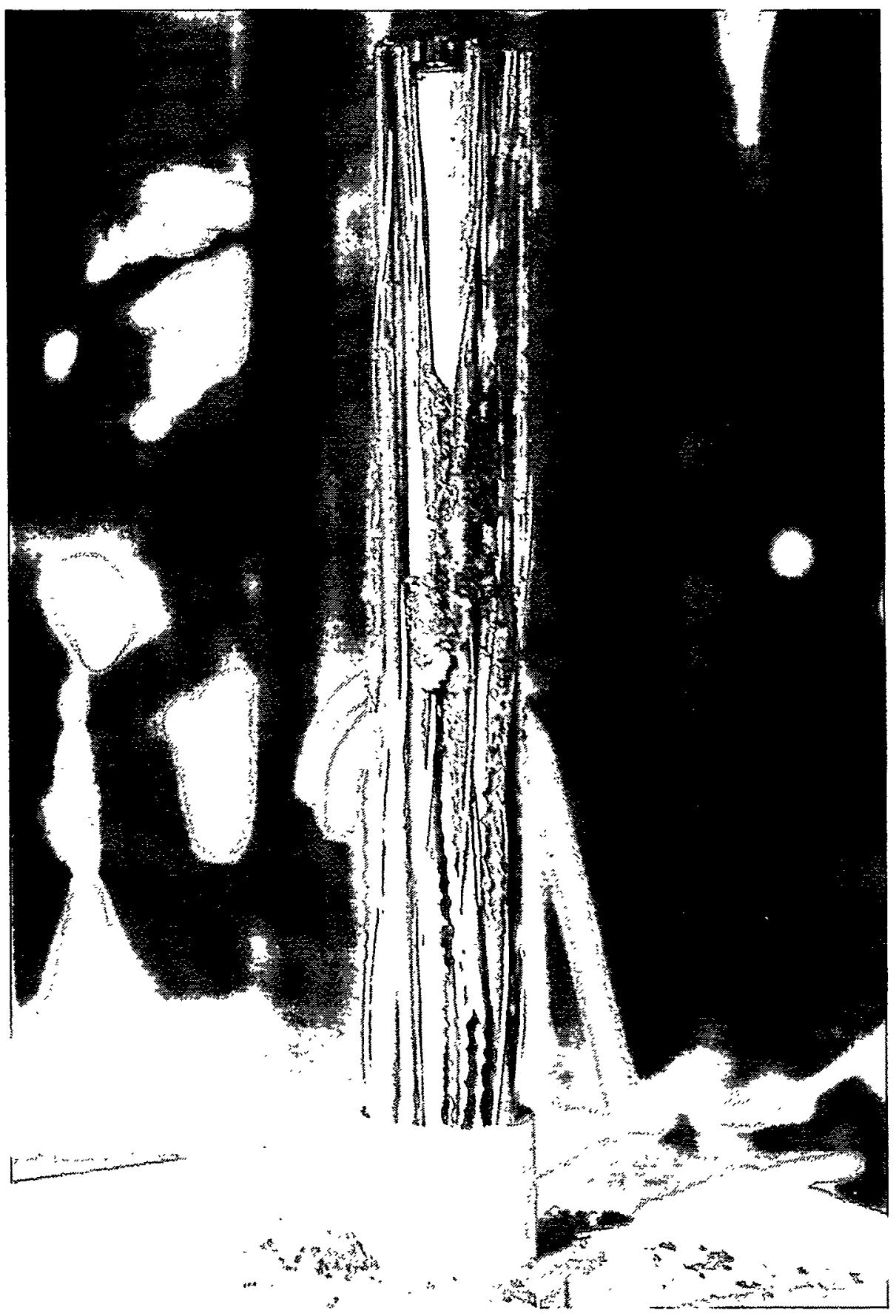

Figure 7. Degraded EBR-II fuel exposed for examination after cutting open the IV-8 container 


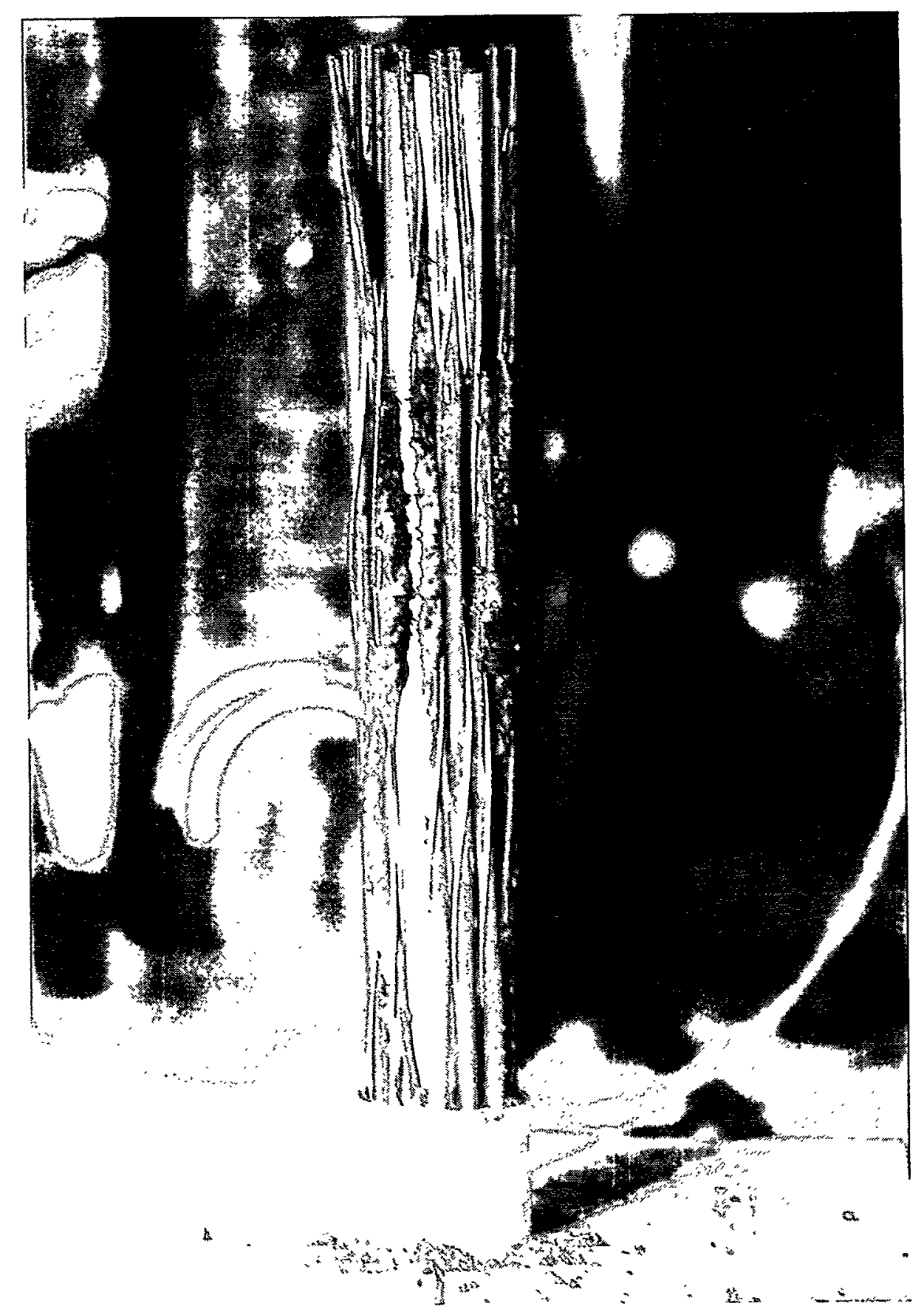

Figure 8. Degraded EBR-II fuel exposed for examination after cutting open the IV-8 container 
cut at 16 inches. Figure 5 shows this element after removal. Loose, coarse fuel oxide powder was found clinging to the cladding and inner container surface. This dark brown/black particulate appeared to have a consistency similar to that of damp beach sand as it was remotely handled in-cell. A 10 gram sample was obtained and sealed in a SADD-Z type sample container for transfer to the Analytical Laboratory via the pneumatic transfer system. The serrated nature of the longitudinal cladding breach, which ran the whole length of the fuel region, was evident. The remaining 11 elements were not easily pulled from the container and the second circumferential cut was made. Figures 6,7 and 8 show various views of the fuel during removal from the container. The cylindrical central post seen in the figures is part of the container's configuration and the elements surround it concentrically in random fashion. With considerable manual force on the remote slave-manipulators, 8 of the remaining elements were eventually pulled from the debris bed, leaving 3 firmly stuck in place. The solid, almost cement-like nature of the debris bed was unexpected and it suggests uranium oxide particulate resulting from immersion corrosion may not be so easily dispersible outside of the fuel container.

\section{DISCUSSION}

Though further examinations of the fuel/water corrosion products are ongoing, the features described above are consistent with the assessment provided in reference 3 . The chemical environment inside of the container is complex and changes over time as the sodium, fuel, fission products, and cladding constituents react with the water. A simplified picture of the corrosion process is provided below.

The cause of the leaks can now be attributed to improperly tightened lids as evidenced by the position of the lids after retrieval from the pool. Breached fuel element cladding could be seen in the neutron radiographs in many of the containers. This was attributed to cracking of the austenitic cladding whose microstructure was sensitized to stress corrosion cracking by both thermal and irradiation-assisted mechanisms during irradiation in the EBR-II reactor. Normal in-reactor cladding failure of this fuel type occurs by a creep mechanism due to fuel/clad mechanical interaction stress and fission gas pressure. The containers were placed in a pool that had a chloride ion content which varied between $\sim 50$ and $\sim 350$ ppm over the time 
the containers were stored, providing an aggressive environment for stress corrosion cracking to take place.

Upon initial cracking of the cladding, the most rapid reaction which takes place is the oxidation of the sodium bond by the water:

$$
2 \mathrm{Na}+2 \mathrm{H}_{2} \mathrm{O} \rightarrow 2 \mathrm{NaOH}+\mathrm{H}_{2}
$$

Once breached, the oxidation of the fuel alloy can take place by initially reacting with the original container air and/or with liquid water and water vapor according to equations (2) and (3):

$$
\begin{aligned}
& \mathrm{U}+\mathrm{O}_{2} \rightarrow \mathrm{UO}_{2} \\
& \mathrm{U}+2 \mathrm{H}_{2} \mathrm{O} \rightarrow \mathrm{UO}_{2}+2 \mathrm{H}_{2}
\end{aligned}
$$

The hydrogen produced can in turn react with the uranium to form uranium hydride. This byproduct of the uranium corrosion process can also oxidize by an oxygen or water reaction:

$$
\begin{aligned}
& \mathrm{UH}_{3}+\mathrm{O}_{2} \rightarrow \mathrm{UO}_{2}+(3 / 2) \mathrm{H}_{2} \\
& \mathrm{UH}_{3}+2 \mathrm{H}_{2} \mathrm{O} \rightarrow \mathrm{UO}_{2}+(7 / 2) \mathrm{H}_{2}
\end{aligned}
$$

The degradation process likely proceeds as follows. The uranium oxide formed inside the breached cladding jacket tends to further stress the cladding due to volume expansion with respect to the $\mathrm{U}$ metal it replaces. A longitudinal crack propagates in the embrittled cladding. As the fuel oxidizes in the vicinity of the cladding crack and the cladding crack grows, fuel oxide particles spall off and form the debris bed seen in the radiographs. The fission gases, 
xenon and krypton, and hydrogen from the corrosion reactions accumulate in the container atmosphere as the fuel and sodium oxidizes. Gas pressures build inside the container, but since the container is not gas or water tight, vent as bubbles into the pool. Because the corrosion process was well progressed in the case of the three containers gas-sampled, the original oxygen in the container had long been depleted by chemical reactions or had been flushed out of the container through the leak. The latter would also explain the lack of nitrogen gas found in the samples. This process leads to an essentially pure hydrogen gas atmosphere, with much less oxygen than is required for ignitable mixtures.

The presence of significant quantities of elemental $\mathrm{Na}$ and $\mathrm{Cs}$ released into the water raises the $\mathrm{pH}$ by the formation of $\mathrm{NaOH}$ and $\mathrm{CsOH}$. Simple litmus paper indicators gave readings of $\mathrm{pH} 14$. Taking the measured $\mathrm{Na}$ and (total elemental) Cs concentrations (1403 and $657 \mathrm{ppm}$, respectively) as hydroxides, a pH of $\sim 12.8$ was calculated for the IV-8 container at the time of examination. Tyfield ${ }^{4}$ reported a modest (50\%) decrease in reactor grade uranium corrosion rate in raising the $\mathrm{pH}$ from 6.5 to 11.5 by adding $\mathrm{NaOH}$. The issue of caustic corrosion of the 300 series stainless steel cladding alloys and container material was mentioned in reference 3. This effect should not be a problem for the integrity of the containers nor markedly accentuate the stress corrosion cracking of the cladding due to the low temperatures experienced in the pool.

A rough estimate of the extent of oxidation expected for the fuel in the IV-8 container is instructive, similar to that done in reference 3 for the general case. For the IV-8 container, the fuel is the EBR-II MK-IA type, which unlike the MK-II fuel modelled in reference 3, is not expected to corrode as fast due to its low level of interconnected porosity and hence lower surface area. This fuel experiences less swelling due to its low burnup (maximum of 2.3\% heavy metal for this particular fuel batch) and constraint by the tighter fitting cladding. A typical fuel pin contains $\sim 61$ grams of uranium and has an as-irradiated surface area of $\sim 40$ $\mathrm{cm}^{2}$. Taking the uranium corrosion rate [3] in oxygen-starved water at $25^{\circ} \mathrm{C}$ as $\sim 0.22$ grams $\mathrm{U}$ per $\mathrm{cm}^{2}$ per year, a single pin fully exposed to water/water vapor can initially oxidize at the rate of $\sim 9$ grams $U$ per year. Considering that the IV-8 container had been in the pool for 16 years, the amount of fuel debris seen in figure 2 is not unexpected. 
The potential for considerable hydrogen production is present in this system, though severe overpressures are not likely since the container contents cannot corrode without an active leak being present to admit water. In addition to some hydrogen produced from water radiolysis and the sodium reaction, uranium corrosion produces most of the hydrogen present via equation (3). For a storage container of this type holding 12 fuel elements, complete oxidation of the uranium present (assuming no $\mathrm{UH}_{3}$ production) can produce $\sim 6$ moles of hydrogen gas. An empty container has $~ 1.0$ litres of freespace, so that $\sim 150$ atmospheres pressure could be produced, though this would increase since the volume is reduced by fuel and water. The fact that the pressures measured in two of the containers were only 2-3 atmospheres (even after stopping the venting by tightening the lids in the hotcell upon receipt) attests to the fact that natural venting would prevent significant hydrogen gas pressure buildup in the storage pool.

As seen in Table $\mathrm{V}$, a progressive increase in activity is observed in going from the pool to the overpack container to the fuel container water. It is clear that even though the fuel containers are still mechanically capped, leakage is ongoing since the overpack containers' Cs-137 activities exceed the pool values by factors of 200 and $5.5 \times 10^{4}$. For Cs-137, the increase in specific activity in the IV-8 fuel container water is $\sim 2.3 \times 10^{8}$ times the typical pool value. A fuel handling accident which would instantaneously release the Cs-137 source term directly into the ICPP-603 pool would add $\sim 5.6 \mathrm{Ci}$ to the 1.5 million gallons of water. If distributed uniformly and left unpurified, the resulting activity is calculated to be $\sim 10^{-3}$ microcuries/ml. This is a factor of 10 times the current Cs-137 background level shown in Table V.

Source term computer code calculations [5] for the total ICPP pool inventory of EBRII fuel were scaled to provide estimates for the radionuclide content of the specific fuel stored in the IV-8 container. This calculation showed that the Cs-137 activity in the container water is equivalent to that of $\sim 1.5 \mathrm{EBR}$-II MK-IA type fuel elements. The total elemental Cs content was measured out of cell by atomic absorption spectroscopy and found to be $\sim 657 \mathrm{ppm}$. This 
is reasonably consistent with the Cs-137 data obtained independently (by hotcell gamma spectroscopy) and is roughly equivalent to the expected source term of one fuel element. The $\mathrm{Sr}-90$ in the container water is $\sim 0.005 \%$ of one fuel element's inventory. The quantities of Cs and $\mathrm{Sr}$ in the water appear reasonable considering the amount of fuel which has visibly turned to debris, taking into account the difference in the solubilities of these two radionuclides. Tyfield [6] reports that cesium release after uranium corrosion approaches $100 \%$ while that of strontium is less than 10\%. Fonnesbeck et al. [7] reported Sr-90 and Cs- 137 releases from low burnup uranium blanket fuel corroded in water at $90^{\circ} \mathrm{C}$. After one month, the sample which showed extensive sludge formation had released $\sim 0.01 \%$ of the $\mathrm{Sr}-90$ and $\sim 18 \%$ of the original Cs-137 present.

Further characterization of the fuel debris in the container is planned to verify what phases are present and to determine the proper stabilization treatment for this material. If it is determined that uranium hydride has formed, ignition temperature measurements will be attempted.

\section{CONCLUSIONS}

EBR-II fuel containers stored in the ICPP-603 pool at the Idaho National Engineering and Environmental Laboratory have leaked water due to improper lid closure. Fuel cladding rupture and uranium corrosion produced a debris bed at the bottom of some containers. Container headspace gas was found to be essentially pure hydrogen. Radioactive cesium was present in high concentrations in the water.

\section{ACKNOWLEDGMENTS}

This work was supported by the U. S. Department of Energy, Reactor Systems, Development and Technology, under contract W-31-109-Eng-38 and U. S. Department of Energy, Assistant Secretary for Environmental Management under DOE Idaho Operations Office Contract DE-AC07-94ID13223. The author would like to thank the staff at HFEF and the Analytical Laboratory for their efforts. 


\section{REFERENCES}

[1] "Draft Environmental Impact Statement for the Treatment and Management of Sodium-Bonded Spent Nuclear Fuel", DOE/EIS-0306D, July 1999.

[2] R. E. Einziger and B. R. Seidel, "Irradiation Performance of Metallic Driver Fuel in Experimental Breeder Reactor II to High Burnup," Nucl. Tech., 50, 25 (1980).

[3] R. G. Pahl, E. M. Franklin and M. A. Ebner, "Technical Assessment of Continued Wet Storage of EBR-II Fuel”, p. 223, Proceedings of the Embedded Topical Meeting on DOE Spent Nuclear Fuel and Fissile Management Meeting, June 16-20, 1996, Reno, NV.

[4] S. P. Tyfield, "Corrosion of Reactor Grade Uranium in Aqueous Solutions Relevant to Storage and Transport," Nucl. Energy, 27, No. 2, 91, (1988).

[5] J. R. Liaw, Argonne National Laboratory, unpublished data, February 1998.

[6] S. P. Tyfield, "The Corrosion of Reactor Grade Uranium in Aqueous Solutions", Proceedings of the Nuclear Fuel Performance Conference held in Stratford-upon-Avon on March 25-29, 1985.

[7] J. E. Fonnesbeck, J. R. Krsul and S. G. Johnson, "EBR-II Blanket Fuel Leaching Test Using Simulated J-13 Well Water", p. 715, Proceedings of the Third Topical Meeting on DOE Spent Nuclear Fuel and Fissile Management Meeting, September 8-11, 1998, Charleston, SC. 
Distribution for ANL-00/9

Internal:

R. W. Benedict

J.R. Krsul

D.C. Crawford

C. E. Lahm

R. N. Elliott

R.G. Pahl (10)

J. E. Fonnesbeck

D.L. Porter

K. M. Goff

T.C. Totemeier

S.L. Hayes

L.C. Walters

B.A. Hilton

TIS Files

External:

R. Bratton (BBWI)

M.A. Ebner (BBWI)

C. A. Dahl (BBWI)

DOE-OSTI (2)

ANL-E Library

ANL-W Library 